\title{
Cavitary pulmonary metastases
}

\author{
M. RAY CHAUDHUR I \\ Department of Pathology, The London Chest Hospital, London, E.2
}

\begin{abstract}
Cavitation in pulmonary metastases is more common than might be supposed from the small number of cases (75) previously reported. Twenty-five cases of cavitary pulmonary metastases were seen at the London Chest Hospital from 1964 to 1969. The primary sites were the large intestine (8), opposite lung (4), cervix (3), stomach, oesophagus, pancreas, and larynx (2 each) and anal canal and kidney (1 each). The size of the cavities ranged from 1.0 to $6.0 \mathrm{~cm}$., and their wall thickness from 0.3 to $2.5 \mathrm{~cm}$. Only in three cases was there an identifiable communication with the bronchial tree and only in these three cases were neoplastic cells found in the sputum. The main microscopic feature was vascular invasion, which was found in the vicinity of every metastasis ; thrombosis was seen in 14 cases. It seems that the principal cause of necrosis and subsequent cavitation in metastatic tumours of the lung is interference with their blood supply by vascular involvement.
\end{abstract}

Cavitation in pulmonary metastases is thought to be uncommon. Spontaneous cavitation of primary lung tumours is frequent, but comparatively few cases of secondary lung tumours showing cavitation have been reported. Bristowe (1871) first described cavitation in a pulmonary metastasis from a carcinoma of the pharynx, diagnosed at necropsy. Break-down of secondary sarcomas and Hodgkin's disease in lung has also been reported (Farrell, 1935 ; Efskind and Wexels, 1952). Minor (1950), in a series of 314 cases with lung secondaries, found only four nodular carcinomatous metastases with evidence of cavitation. LeMay and Piro (1965) observed that the primary in cases of cavitary pulmonary metastases may be in any part of the body.

\section{METHODS AND MATERIALS}

Twenty-five cases of cavitating pulmonary metastases were observed in a combined radiological and histological survey covering the years 1964 to 1969 at the London Chest Hospital. The lungs received from the operating theatre or the postmortem room were fixed and sliced so that the relation of the necrotic areas to the bronchi could be explored. Blocks were chosen for microscopical examination. Besides haematoxylin and eosin stain, Verhoeff-van Gieson was used to evaluate the vascular factor.

OBSERVATIONS There were 14 men and 11 women. Their ages ranged from 31 to 75 years, the average being 60 years; the figures for each decade were as follows:

$$
\begin{array}{rllr}
30-39 & \ldots & \ldots & 3 \text { cases } \\
40-49 & \ldots & \ldots & 1 \text { case } \\
50-59 & \ldots & \ldots & 5 \text { cases } \\
60-69 & \ldots & \ldots & 11 \text { cases } \\
70-79 & \ldots & \ldots & 5 \text { cases }
\end{array}
$$

The average age for primary carcinoma of the lung is 57 years (Belcher and Anderson, 1965).

The deposits were multiple (from 4 to 10) in 17 cases and single in 8 cases. The multiple deposits were scattered at random over both lung fields (Fig. 1), though 6 of the 8 single deposits occurred in the lower lobes (Fig. 2). The sites of the primaries are listed in Table I. The diameter of these pulmonary deposits ranged from 3.0 to $8.5 \mathrm{~cm}$. Most of them were round or ovoid and their outline was usually smoother than that of a primary carcinoma (Fig. 3). In many cases the surrounding lung tissue was compressed, forming a false capsule.

The cavities varied in size, ranging from less than 1.0 to $6.0 \mathrm{~cm}$., and had ragged walls 0.3 to $2.5 \mathrm{~cm}$. thick. Most of them contained air but one was filled with blood and two contained necrotic material. No fungus was identified in the contents or the walls of the cavities. In three cases dissection revealed communication with the adjacent bronchial tree. In the remainder, no connection was identified, but the presence of air in the cavity showed that one must have existed.

The sputum was searched for neoplastic cells in every case, but they were found only in the three 
T A B L E I

PRESENT SERIES OF CAVITARY PULMONARY METASTASES

\begin{tabular}{|c|c|c|c|c|c|c|c|c|c|c|}
\hline \multirow{2}{*}{ No. } & \multirow{2}{*}{ Name } & \multirow{2}{*}{ Age } & \multirow{2}{*}{ Sex } & \multirow{2}{*}{ Primary Site } & \multicolumn{2}{|c|}{ Pulmonary Lesions } & \multirow{2}{*}{$\begin{array}{l}\text { Cavity Size } \\
\text { (cm.) }\end{array}$} & \multirow{2}{*}{$\begin{array}{l}\text { Wall } \\
\text { Thickness } \\
\text { (cm.) }\end{array}$} & \multirow{2}{*}{$\begin{array}{l}\text { Sputum } \\
\text { Cytology }\end{array}$} & \multirow{2}{*}{ Histopathology } \\
\hline & & & & & Cavitating & Solid & & & & \\
\hline $\begin{array}{l}1 \\
2\end{array}$ & $\begin{array}{l}\text { A.B. } \\
\text { E.B. }\end{array}$ & $\begin{array}{l}51 \\
52\end{array}$ & $\begin{array}{l}\mathbf{M} \\
\mathbf{M}\end{array}$ & $\begin{array}{l}\text { Colon } \\
\text { Larynx }\end{array}$ & $\begin{array}{r}11 \\
1\end{array}$ & - & $\begin{array}{l}2 \times 2 \times 1.4 \\
4 \times 5 \times 4.5\end{array}$ & $2 \cdot 5$ & $\begin{array}{l}\text { Negative } \\
\quad,,\end{array}$ & $\begin{array}{l}\text { Adenocarcinoma } \\
\text { Squamous-cell } \\
\text { carcinoma }\end{array}$ \\
\hline $\begin{array}{l}3 \\
4\end{array}$ & $\begin{array}{l}\text { H.B. } \\
\text { I.C. }\end{array}$ & $\begin{array}{l}35 \\
66\end{array}$ & $\begin{array}{l}\mathbf{M} \\
\mathbf{F}\end{array}$ & $\begin{array}{l}\text { Pa icreas } \\
\text { Opposite lung }\end{array}$ & $\begin{array}{l}1 \\
1\end{array}$ & $\overline{4}$ & $\begin{array}{l}2 \times 1.5 \times 1 \cdot 2 \\
1 \times 1.5 \times 1\end{array}$ & $\begin{array}{l}0.8 \\
0.6\end{array}$ & ", & $\begin{array}{l}\text { Adenocarcinoma } \\
\text { Alveolar-cell } \\
\text { carcinoma }\end{array}$ \\
\hline $\begin{array}{l}5 \\
6\end{array}$ & $\begin{array}{l}\text { M.D. } \\
\text { N.G. }\end{array}$ & $\begin{array}{l}69 \\
59\end{array}$ & $\begin{array}{l}\mathbf{F} \\
\mathbf{F}\end{array}$ & $\begin{array}{l}\text { Caecum } \\
\text { Opposite lung }\end{array}$ & $\begin{array}{l}1 \\
1\end{array}$ & $\overline{2}$ & $\begin{array}{l}1.2 \text { diam. } \\
1.2 \times 1 \times 1\end{array}$ & $\begin{array}{l}0 \cdot 4 \\
0 \cdot 3\end{array}$ & ,", & $\begin{array}{l}\text { Squamous-cell } \\
\text { carcinoma }\end{array}$ \\
\hline $\begin{array}{l}7 \\
8 \\
9\end{array}$ & $\begin{array}{l}\text { L.H. } \\
\text { A.H. } \\
\text { F.L. }\end{array}$ & $\begin{array}{l}64 \\
59 \\
74\end{array}$ & $\begin{array}{l}\mathbf{F} \\
\mathbf{M} \\
\mathbf{M}\end{array}$ & $\begin{array}{l}\text { Oesophagus } \\
\text { Stomach } \\
\text { Anal canal }\end{array}$ & $\begin{array}{l}2 \\
1 \\
1\end{array}$ & $\begin{array}{l}4 \\
- \\
-\end{array}$ & $\begin{array}{l}1 \cdot 5 \text { diam } \\
2 \times 2 \times 1 \\
3 \times 2 \times 2\end{array}$ & $\begin{array}{l}0.4 \\
0.9 \\
1\end{array}$ & ,", & $\begin{array}{l}\text {,, } \\
\text { Sdenocarcinoma } \\
\text { Squamous-cell } \\
\text { carcinoma }\end{array}$ \\
\hline $\begin{array}{l}10 \\
11 \\
12\end{array}$ & $\begin{array}{l}\text { C.L. } \\
\text { A.O. } \\
\text { I.P }\end{array}$ & $\begin{array}{l}68 \\
62 \\
47\end{array}$ & $\begin{array}{l}\mathbf{M} \\
\mathbf{M} \\
\mathbf{F}\end{array}$ & $\begin{array}{l}\text { Colon } \\
\text { Pancreas } \\
\text { Cervix uteri }\end{array}$ & $\begin{array}{l}1 \\
1 \\
3\end{array}$ & $\frac{3}{2}$ & $\begin{array}{l}1.5 \text { diam. } \\
3 \times 4 \times 3 \cdot 2 \\
1 \text { to } 1.5\end{array}$ & $\begin{array}{l}0.3 \\
0.9 \\
0.5\end{array}$ & Positive & Adenocarcinoma \\
\hline 13 & P.P. & 70 & $\mathbf{F}$ & , , & 1 & 3 & $1 \times 2 \cdot 2 \times 2$ & 0.9 & Negative & $\begin{array}{l}\text { carcinoma } \\
\text { Squamous-cell } \\
\text { carcinoma }\end{array}$ \\
\hline $\begin{array}{l}14 \\
15 \\
16 \\
17 \\
18 \\
19 \\
20 \\
21 \\
22\end{array}$ & $\begin{array}{l}\text { M.S. } \\
\text { A.S. } \\
\text { B.S. } \\
\text { E.S. } \\
\text { G.S. } \\
\text { J.M.S. } \\
\text { A.S. } \\
\text { J.P.S. } \\
\text { H.T. }\end{array}$ & $\begin{array}{l}31 \\
69 \\
71 \\
74 \\
65 \\
65 \\
64 \\
38 \\
75\end{array}$ & $\begin{array}{l}\mathbf{F} \\
\mathbf{M} \\
\mathbf{F} \\
\mathbf{M} \\
\mathbf{M} \\
\mathbf{F} \\
\mathbf{M} \\
\mathbf{F} \\
\mathbf{M}\end{array}$ & $\begin{array}{l}\text { Kidney } \\
\text { Colon } \\
\text { Stomach } \\
\text { Colon } \\
\text { Caecum } \\
\text { Colon } \\
\text { Opposite lung }\end{array}$ & $\begin{array}{l}1 \\
1 \\
2 \\
1 \\
1 \\
2 \\
1 \\
2 \\
1\end{array}$ & $\begin{array}{l}- \\
4 \\
6 \\
3 \\
2 \\
6 \\
2 \\
4 \\
6\end{array}$ & $\begin{array}{l}3 \times 3.5 \times 3 \\
2 \times 2.5 \times 3 \\
1.5 \text { to } 2 \\
1.8 \times 2 \times 2 \\
4 \times 3.2 \times 3 \\
1.2 \text { to } 3 \\
3 \times 2.5 \times 2.7 \\
1 \text { to } 1.5 \\
5 \times 4 \times 4\end{array}$ & $\begin{array}{l}1 \cdot 2 \\
0 \cdot 9 \\
0 \cdot 5 \\
0 \cdot 8 \\
1 \cdot 5 \\
1 \cdot 0 \\
1 \cdot 9 \\
0 \cdot 3 \\
1 \cdot 2\end{array}$ & $\begin{array}{c}\qquad, \\
,, \\
,, \\
,, \\
\text { Positive } \\
\text { Negative } \\
\text { Positive }\end{array}$ & $\begin{array}{c}\text { carcinoma } \\
\text {,, } \\
\text { Hypernephroma } \\
\text { Adenocarcinoma } \\
\text {,, } \\
,, \\
,, \\
\text { Squamous-cell }\end{array}$ \\
\hline $\begin{array}{l}23 \\
24 \\
25\end{array}$ & $\begin{array}{l}\text { S.W. } \\
\text { E.W. } \\
\text { A.W. }\end{array}$ & $\begin{array}{l}62 \\
59 \\
69\end{array}$ & $\begin{array}{l}\mathbf{M} \\
\mathbf{M}\end{array}$ & $\begin{array}{l}\text { Larynx } \\
\text { Oesophagus }\end{array}$ & $\begin{array}{l}1 \\
2 \\
1\end{array}$ & $\begin{array}{l}8 \\
3 \\
3\end{array}$ & $\begin{array}{l}1.2 \times 1 \times 1.4 \\
1.5 \text { to } 1.8 \\
5 \times 6 \times 4.5\end{array}$ & $\begin{array}{l}0.3 \\
0.9 \\
0.9\end{array}$ & $\begin{array}{c}\text { Negative } \\
\quad,,\end{array}$ & $\begin{array}{c}\text { carcinoma } \\
,, \\
, "\end{array}$ \\
\hline
\end{tabular}

FIG. 1. Multiple metastases in both lungs from a carcinoma of the colon. The metastatic growth in the superior segment of the right lower lobe shows distinct cavitation.

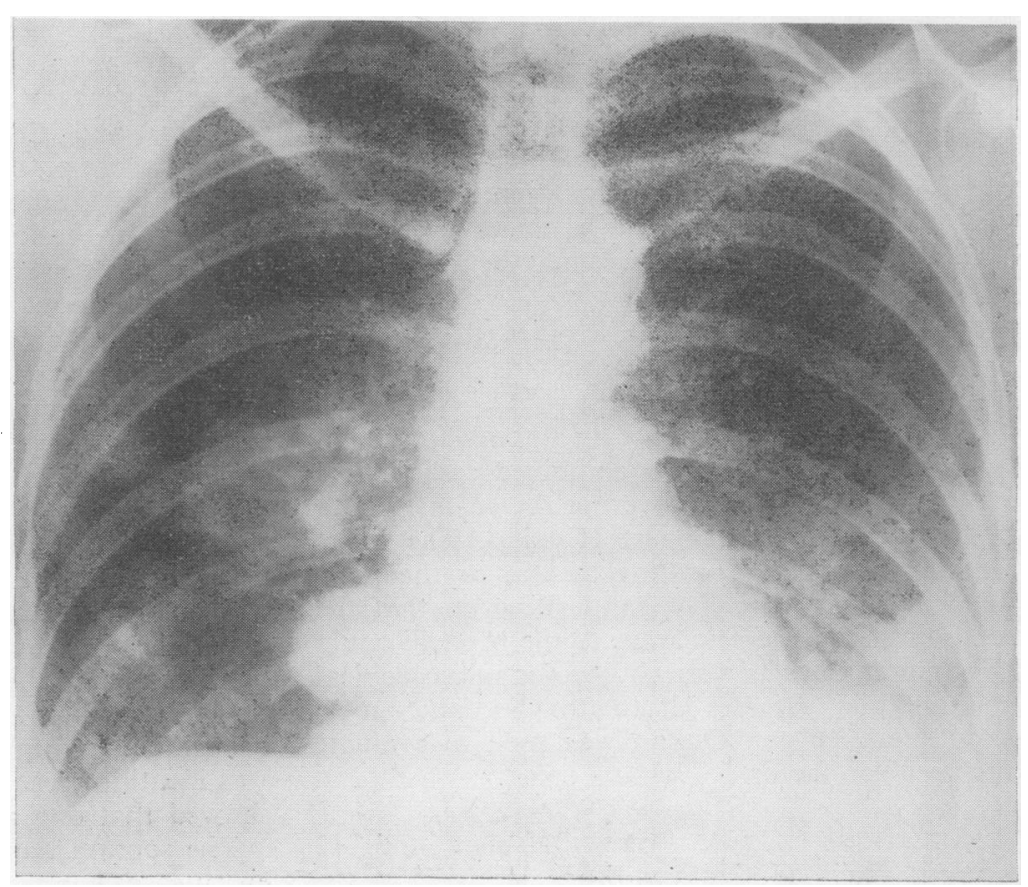




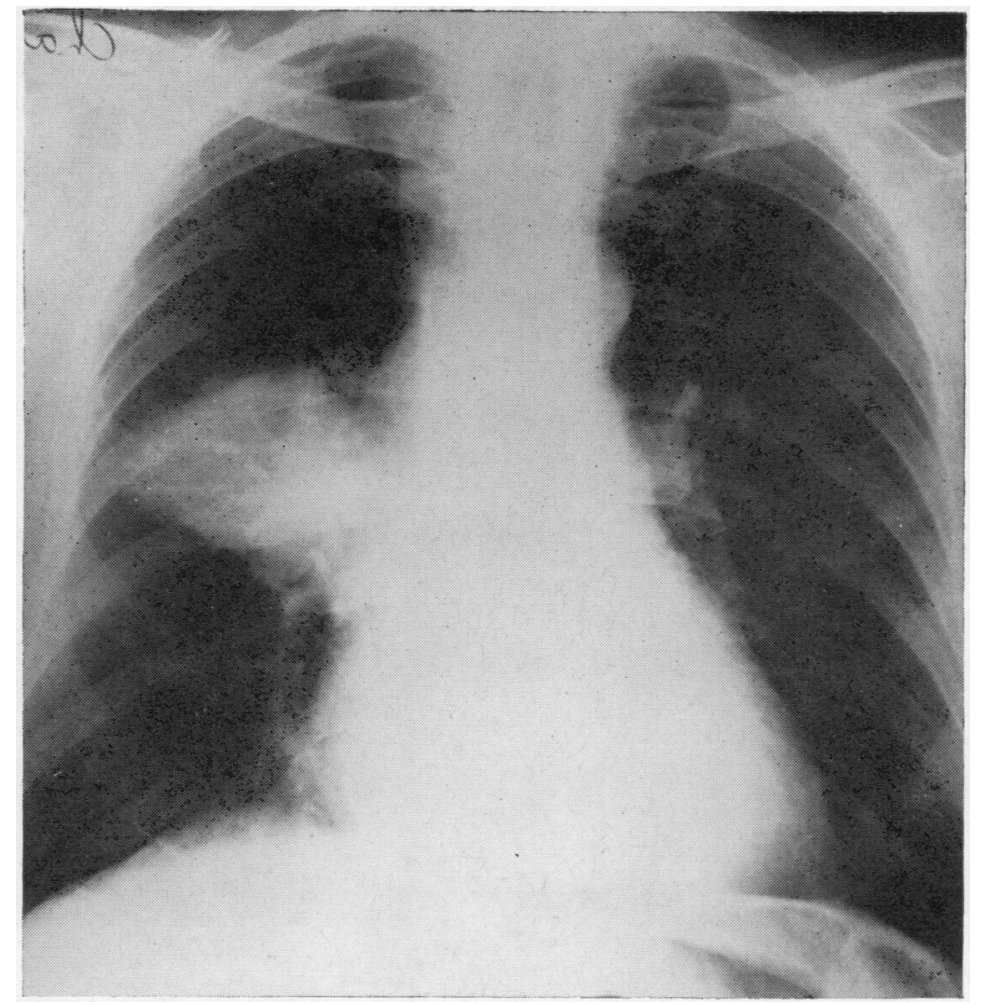

FIG. 2

FIG. 2. A large cavitary metastasis in the superior segment of the right lower lobe from a caecal adenocarcinoma.

FIG. 3. Radiological details of a cavitary metastasis in the right lower lobe after inflation (surgical specimen).

FIG. 3

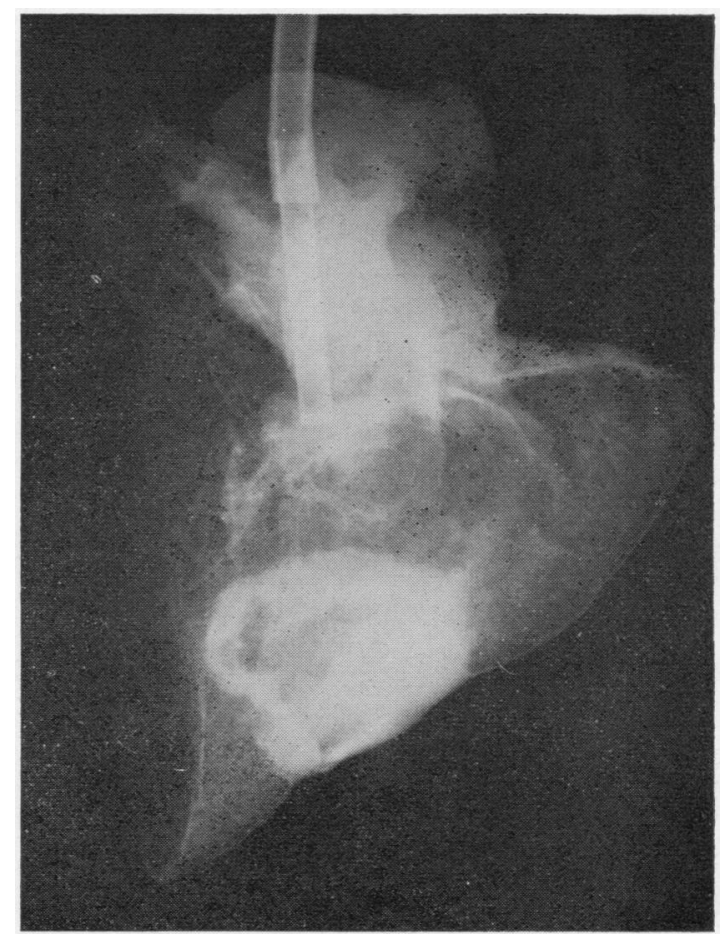




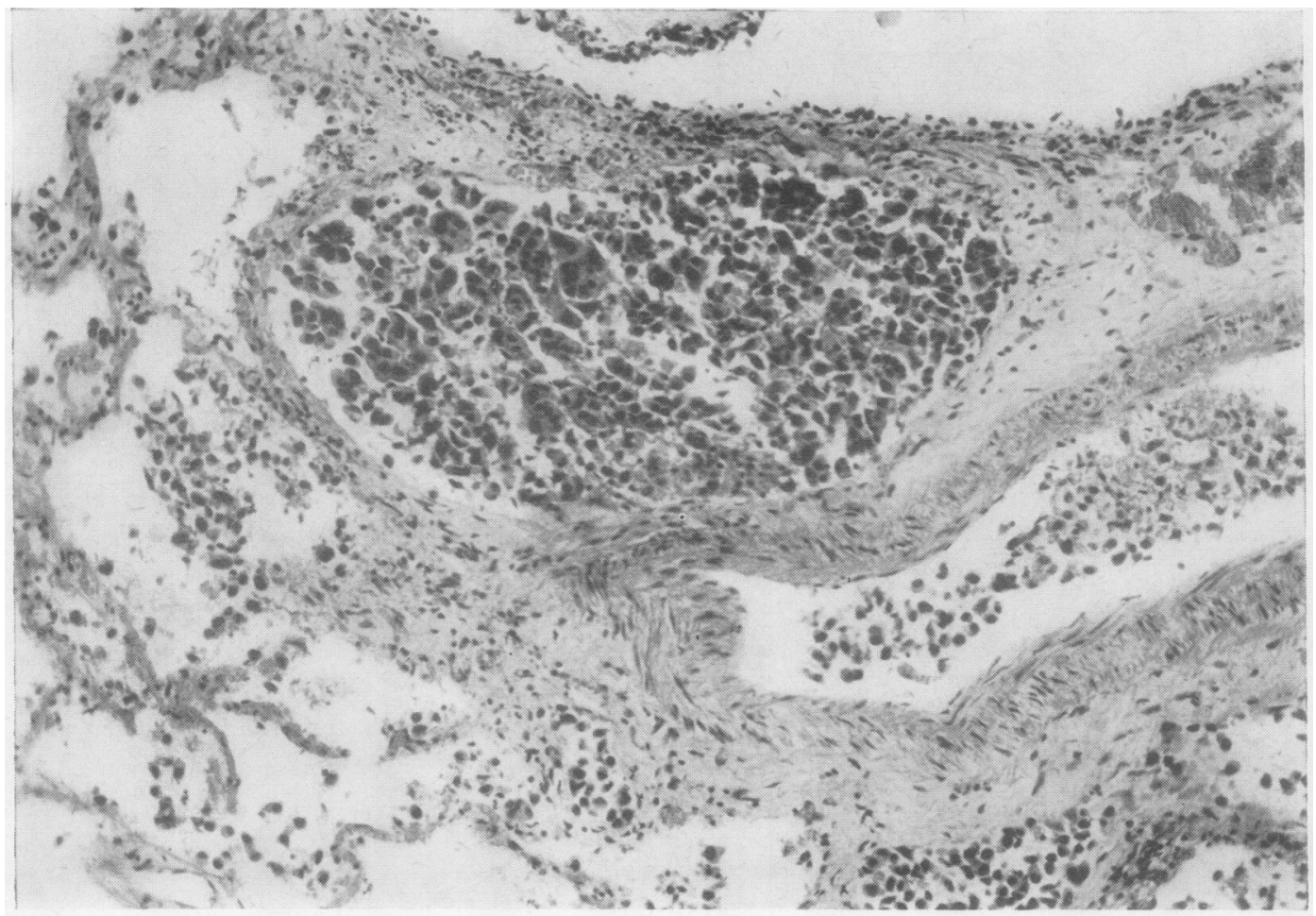

FIG. 4. Typical invasion of a pulmonary artery. H. and E. $\times 145$.

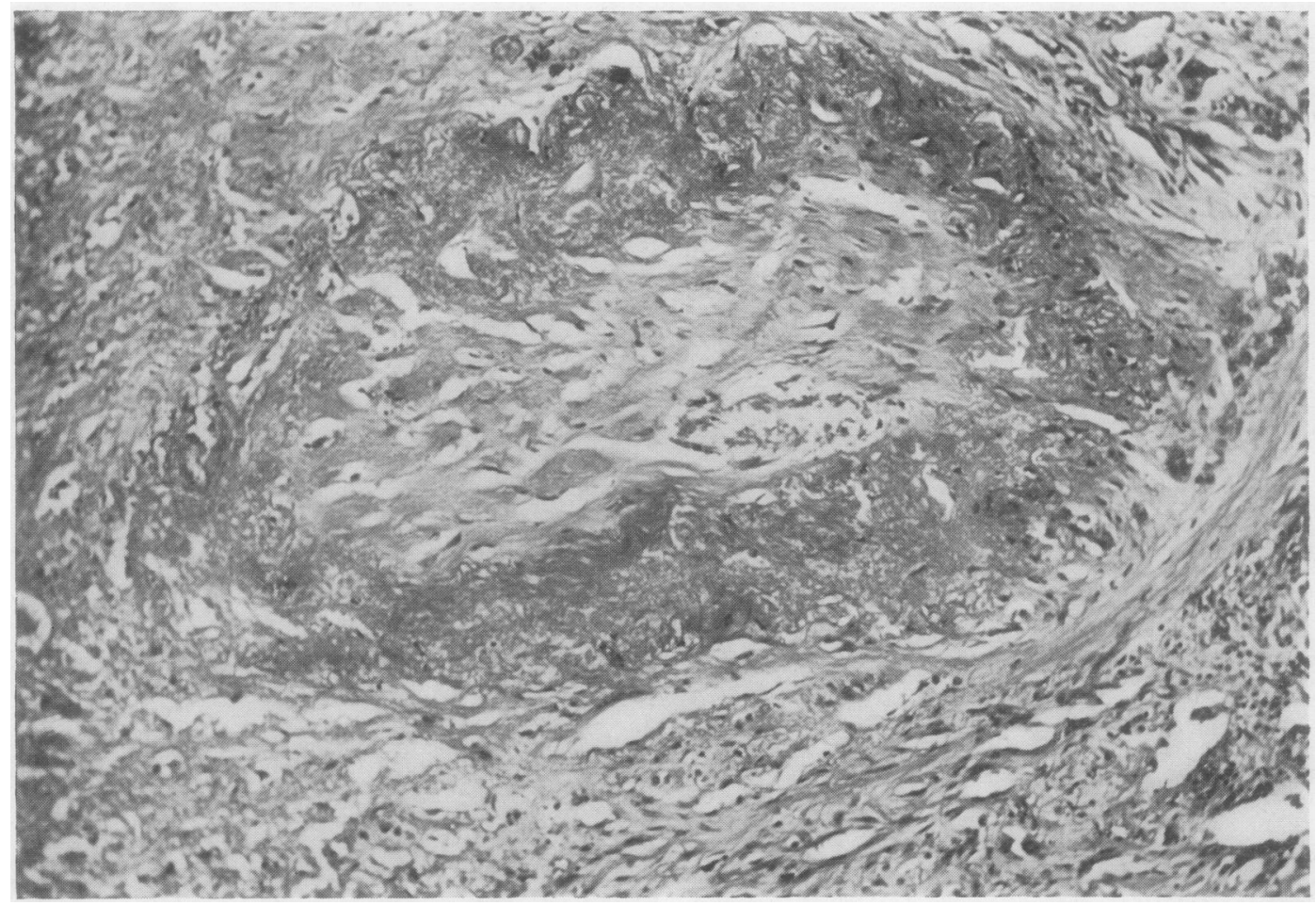

FIG. 5. Organization in a completely thrombosed pulmonary artery near the necrotic area of a metastasis. $H$. and $E . \times 145$. 


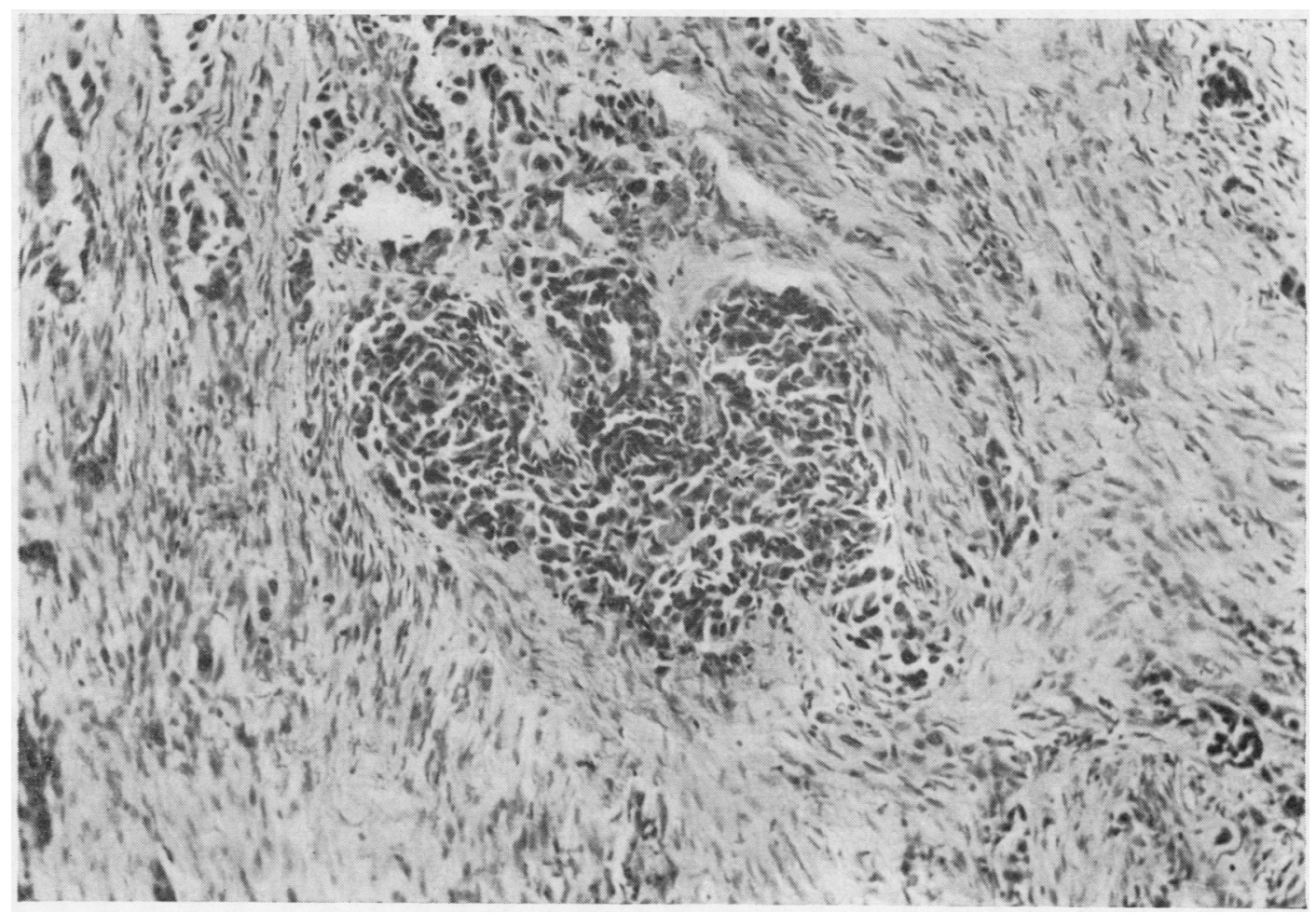

FIG. 6. Carcinomatous invasion and residual thrombus in a pulmonary artery near the necrotic area of a metastasis. H. and E. $\times 145$.

cases where definite bronchial communication was established by dissection.

Vascular invasion was frequently encountered on microscopical examination. A case was regarded as 'positive' whether the vessel invaded was large, medium-sized, or small, and whether many vessels were invaded or only one. The term 'positive invasion' was used to mean infiltration right through the media so that growth was embedded in the intima or in contact with blood or thrombus (Pryce and Walter, 1960). In all 25 cases there was extensive vascular invasion (Fig. 4 ), and in 14 cases the vessels in close proximity to the necrotic area of the metastasis showed thrombosis as well (Figs 5 and 6).

\section{DISCUSSION}

The vascular supply of a lung cancer is richest at the margins. A growing bulky tumour outstrips its blood supply and central ischaemia leads to necrosis. Infection may or may not supervene. When communication with an adjacent bronchus permits expectoration of the material, a cavity soon results. Salzman, Reid, and Ogura (1953) postulated that erosion of the bronchial wall by the lesion and discharge of the necrotic tissue into the bronchial tree was the most likely cause of cavitation. In his large series of pulmonary metastases, Minor (1950) was occasionally able to determine the type of neoplasm from a bronchial biopsy or from pieces of tissue expectorated. In the present series, bronchoscopy (done in 19 patients) revealed partial occlusion of the corresponding bronchi in four cases and complete occlusion in two. However, none had a positive bronchial biopsy and none of the patients coughed up pieces of malignant tissue.

Gellman and Jelliffe (1957) observed that metastatic deposits in cervical lymph nodes from keratin-producing squamous-cell carcinoma of the head and neck region frequently soften and become fluctuant. They suggested that cancer cells could be inhaled and could set up pulmonary metastases which would then cavitate. However, there is no evidence that direct implantation can 
occur and, in any case, metastases from other cancers are just as prone to cavitation.

Laforet and Laforet (1957) collected 145 cases of cavitating carcinoma of the lung from a large series of both primary carcinomas and secondary metastases, based on both radiological and nakedeye examination. Only 10 were secondary to tumours elsewhere in the body (Table II). Many of the metastatic lesions were filled with solid or necrotic material and simulated cavities radiologically. This misleading appearance was thought to result from a physico-chemical change in the contents which raised their lipid concentration. This phenomenon is stated to be particularly common among mucus - secreting adenocarcinomas, which have a cystic tendency throughout the life of the tumour, presumably owing to transmission of secretory function to the metastatic deposits. Certain pancreatic neoplasms are claimed to produce metastases which retain the capacity to secrete proteolytic and lipolytic enzymes. These functioning tumours are alleged to digest both their own substance and the surrounding normal tissue and to produce cavities (Berger and Thompson, 1967; Zorini, 1967).
However, this hypothesis has never been proved. Two cases of this series were metastases from primary pancreatic tumours, but neither of them revealed any histological evidence of proteolytic or lipolytic changes.

Dodd and Boyle (1961) found 10 squamous tumours in their series of 16 cavitary metastases (Table II) and suggested that cavitation depends on the inherent qualities of squamous metastases rather than on their blood supply. In this series only 11 out of 25 were squamous tumours, but it is certainly true that metastases from squamous carcinomas, like primary squamous tumours, are extremely prone to necrosis, which sometimes involves nodules so small that inadequacy of the blood supply can hardly be held responsible (case 23). As Dodd and Boyle pointed out, the inherent characteristic of any squamous epithelium is cornification, though in the centre of squamous neoplastic masses, in the absence of air, the endproduct becomes semi-liquid. This process is most evident in the squamous tumours of the head and neck and, to a lesser extent, in those of the cervix and bladder. As a rule, metastases from the head and neck showed earlier and more extensive

T A B L E I I

REPORTED CASES OF CAVITARY PULMONARY METASTASES

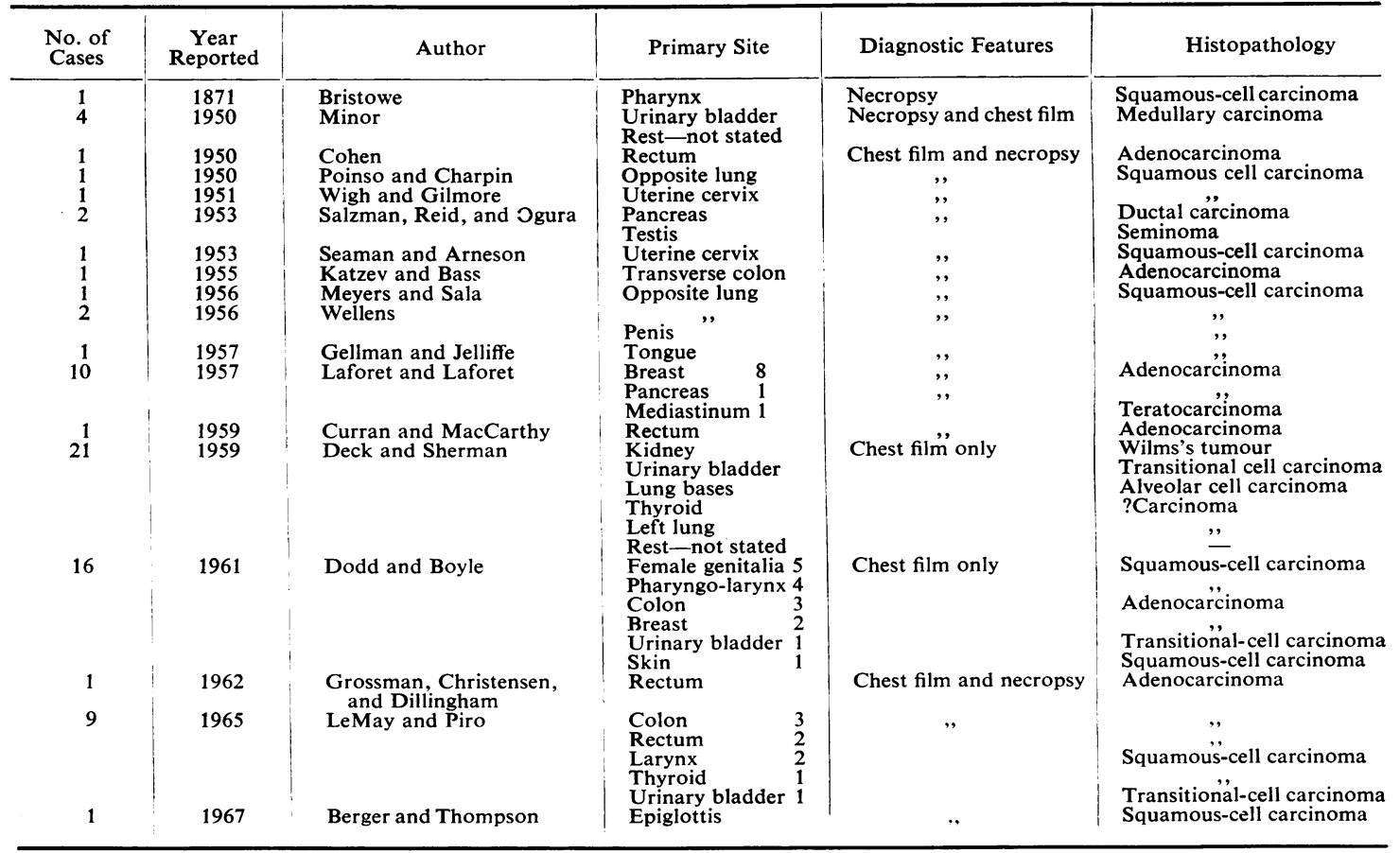


excavation than those from the cervix or urinary bladder. In the usual course of events, following occlusion of an arteriole by a viable mass of tumour cells, the vessel wall is invaded and access to the perivascular spaces is gained. The tumour may then spread interstitially or within the alveoli. Eventually the lung architecture is destroyed and central avascular necrosis ensues. When the tumour breaks into the alveoli there is ample opportunity for communication between its semi-liquid contents and the respiratory passages below the bronchial level. Once the central layers of the epithelium are in contact with air, the process of keratinization is accelerated (case 12) and respiratory motion assists in stripping the dehydrated, stratified material from the cavity walls. Growth meanwhile progresses peripherally, the two processes combining to increase the size of the cavity while maintaining a wall of relatively constant thickness. Seven of the 11 cases of cavitary squamous metastases of the present series showed vascular invasion and thrombosis, and were large enough to indicate that inadequacy of blood supply was responsible for their necrosis and subsequent cavitation, though in some squamous metastases (case 23) necrosis due to their inherent propensity to cornification cannot be ruled out.

Grossman, Christensen, and Dillingham (1962) observed vascular thrombosis in and around the necrotic areas of their case, a cavitary pulmonary metastasis from a carcinoma of the rectum (Table II). They deduced that vascular thrombosis was responsible for necrosis of the metastatic growth, though there was no evidence of bronchial involvement to explain cavity formation. In 14 of the present 25 cases, gross vascular thrombosis had occurred in addition to neoplastic invasion. Seven of these cases were squamous-cell carcinomas and the remainder were adenocarcinomas. Patchy pneumonic consolidation occurred in almost every case, though none showed any evidence of infarction.

It seems logical, therefore, to explain necrosis and subsequent cavitation of metastatic pulmonary tumours mainly in terms of thrombosis and inadequate blood supply.
I am indebted to Dr. K. F. W. Hinson, Director of Pathology, the Hospitals for Diseases of the Chest, and Dr. D. P. Winstanley, consultant pathologist, the London Chest Hospital, for their advice and criticism. I thank the physicians and surgeons of the London Chest Hospital for allowing me to report their patients, Mr. K. G. Moreman, Chester Beatty Institute, for the photographs, and Mr. V. Jones, London Chest Hospital, for technical help.

\section{REFERENCES}

Belcher, J. R., and Anderson, R. (1965). Surgical treatment of carcinoma of the bronchus. Brit. med. J., $1,948$.

Berger, M., and Thompson, J. R. (1967). Cavitary carcinomatosis of the lungs. Dis. Chest, $52,106$.

Bristowe, J. S. (1871). Cancer involving pharynx, larynx, neighbouring lymphatic glands, and lungs. Trans. path. Soc. Lond., 22, 132. Cited by Gellman et al.

Cohen, A. G. (1950). Solitary pulmonary metastasis with detectable bronchial involvement appearing $9 \frac{1}{2}$ years after resection of colon carcinoma. N.Y. St.J. Med., 50, 1848.

Curran, J. D., and MacCarthy, M. T. J. (1959). Cavitary pulmonary metastases. J. Fac. Radiol., (Lond.), 10, 166.

Deck, F. W., and Sherman, R. S. (1959). Excavation of metastatic nodules in the lung. Radiology, 72, 30.

Dodd, G. D., and Boyle, J. J. (1961). Excavating pulmonary metastases. Amer. J. Roentgenol., 85, 277.

Efskind, L., and Wexels, P. (1952). Hodgkin's disease of the lung with cavitation. J. thorac. Surg., 23, 377.

Farrell, J. T., Jr. (1935). Pulmonary metastasis: a pathologic, clinical, roentgenologic study based on 78 cases seen at necropsy. Radio$\log y, 24,444$.

Gellman, D. D., and Jelliffe, A. M. (1957). Cavitating pulmonary metastases. Tubercle (Lond.), 38, 280.

Grossman, J. W., Christensen, R. O., and Dillingham, C. H. (1962). Cystic liquefactive necrosis of metastatic carcinoma in the lung. Cystic liquefactive necrosis
Lovelace Clin. Rev., 1, 143.

Katzev, H., and Bass, H. E. (1955). Cavitation in metastatic pulmonary neoplasm. Dis. Chest, 27, 225.

Laforet, E. G., and Laforet, M. T. (1957). Non-tuberculous cavitary disease of the lungs. Ibid., 31, 665 .

LeMay, M., and Piro, A. J. (1965). Cavitary pulmonary metastases. Ann. intern. Med., 62, 59.

Meyers, D., and Sala, A. M. (1956). Bronchogenic carcinoma with breakdown of primary and metastatic foci in the lungs. Dis. Chest, 30, 673.

Minor, G. R. (1950). A clinical and radiologic study of metastatic pulmonary neoplasms. J. thorac. Surg., 20, 34.

Poinso, R., and Charpin, J. (1950). Cavité "soufflée" et néoplasme bronchique. Poumon, 6, 97.

Pryce, D. M., and Walter, J. B. (1960). The frequency of gross vascular invasion in lung cancer with special reference to arterial invasion. J. Path. Bact., 79, 141.

Salzman, E., Reid, J. H., and Ogura, G. I. (1953). Cavernous metastatic pulmonary carcinoma. Dis. Chest, $23,678$.

Seaman, W. B., and Arneson, A. N. (1953). Solitary pulmonary metastases in carcinoma of the cervix. Obstet. and Gynec., $1,165$.

Wellens, P. (1956). Aspects radiologiques inhabituels des métastases pulmonaires. J. belge Radiol., 39, 339.

Wigh, R, and Gilmore, F. R. (1951). Solitary pulmonary necrosis: a comparison of neoplastic and inflammatory conditions. Radiology, 56, 708.

Zorini, A. O. (1967). Primary carcinomatous cavities of the lung: possible role of neoplastic cell autophagism. Dis. Chest, 52, 329 . 